\title{
Studies of uterine secretions and products of primary cultures of endometrial cells in pigs
}

\author{
D. L. Davis and R. M. Blair \\ Department of Animal Sciences and Industry, Kansas State University, Manhattan, KS 66506, USA
}

\begin{abstract}
The uterus plays a central role in the reproductive biology of mammals. Adaptation of the uterus from an oviparous to a viviparous nature required changes that involved production of a uterine environment that could support the development of the embryo and fetus. Production of a suitable environment includes the synthesis and secretion of products by the uterine endometrium. However, the uterine endometrium is not a single homogeneous unit, but rather consists of several cell populations. Recent accomplishments in cell culture techniques provide a means for examining the contributions and secretory control of different endometrial cell populations. Furthermore, it is possible to recombine specific cell types to study their interaction. It is clear that the luminal epithelium, glandular epithelium and endometrial stroma produce different secretory products. Some secretions (for example uteroferrin) are secreted by only one cell type; others (for example prostaglandins, PGs) are secreted by all types of cell. There is much to be learned about the functions and regulations of endometrial secretions and there are important aspects of the role of the endometrium in pregnancy that present concepts do not address. For example, there is no explanation for the required synchrony between the embryo and uterus before day 10 and the implications of control of the uterine environment by progesterone from day 4 to day 10 are not understood. Almost all of the uterine secretory proteins are produced after day 10 . In this review, we consid̈er the protein and prostaglandin products from the different cell populations of the pig endometrium and propose a model to explain the integration of multiple sources of PGs and multiple regulators of PG secretion. Our purpose is to facilitate a more complete understanding of the individual uterine cell populations and a better understanding of how these cell types interact to function as a complete unit.
\end{abstract}

\section{Introduction}

The endometrium provides an environment that is different from plasma and other extracellular fluids. Important constituents of the uterine luminal environment are the products of de novo synthesis and those derived from blood. For blood-derived molecules, the epithelium is the primary rate-limiting barrier for access to the uterine lumen (McCrae, 1988). In addition, some plasma constituents are taken up intracellularly by the basal surface of the epithelium and then released apically (McCrae, 1988). Most of the discussion in this review will deal with endometrial secretory products, but we suggest that models based on growing uterine epithelium on filters in vitro that divide the culture medium into basal and apical compartments will be useful for studying the selective transport of molecules across the uterine epithelium.

The uterus is programmed for its role partly by the gonadal hormones of the oestrous cycle (Roberts and Bazer, 1988). The uterus of a virgin gilt is therefore appropriately prepared to receive transplanted embryos and can nurture them after transfers at least as late as day 9 (day $0=$ day of onset of oestrus) 
(Polge, 1982). A poorly understood aspect is the requirement for embryo-uterine synchrony (Webel $e t$ al., 1970; Polge, 1982). Initially, the nongravid (cyclic) uterus will support embryos of a similar day of pregnancy. The changes that fulfil the synchrony requirement of early uterine embryos therefore occur without inputs from the embryos. However, the embryos also modify the endometrium to their own programme, as shown in pigs by the response to conceptus oestrogen on days 11-12 (Geisert et al., 1982a). Pope et al. (1990) suggested that production of oestrogen by the most rapidly developing conceptuses advances the uterine environment in a manner that is unacceptable for less developed conceptuses. The nature of the support provided by the endometrium is not completely known, but it continues throughout pregnancy in pigs, in which attachment remains superficial until farrowing (discussed by Roberts and Bazer, 1988).

Questions can be raised about the specific nature of the interaction between uterus and conceptus and the more general concept of providing an environment that is permissive for the conceptus to express its own genetic programme for development. For example, pig embryos can survive and develop to day 11 in the uterus of a gilt ovariectomized on day 6 (Galvin et al., 1990; 1992). The embryos do not survive when ovariectomy is performed on day 4 after mating, probably because ovarian steroids have not yet programmed the environment within the uterus. However, continuous steroid support is clearly not necessary during this early period.

An appropriate question is how similar the embryos developing in a uterus deprived of ovarian steroids are to embryos developing in the uterus of an intact gilt. Embryos in an ovariectomized gilt appear to develop more slowly and are smaller on day 11. This situation is reminiscent of the slow development observed in cultured embryos (Davis, 1985). An emerging view indicates that a certain amount of redundancy occurs in the regulation of conceptus development. Both embryonic and uterine gene products appear to participate, and there is much interest in the potential of uterine growth factors to exert control over some aspects of conceptus growth and development (Simmen and Simmen, 1990). The conceptus may regulate its own development to some extent, but exposure to the uterine environment may be necessary for complete and normal development. Although four-cell embryos will cleave and form blastocysts in vitro, they have fewer cells and a reduced developmental potential when transplanted to recipients (Davis, 1985). In addition, there is a limitation on the period for which normal development in vitro is possible and blastocyst elongation in culture has not been reported.

As pointed out by Roberts and Bazer (1988), there has been much speculation about the roles of the constituents of the uterine fluids "... but few definitive results have emerged". All these considerations draw attention to the need for experimental models that permit studies of the interactions between the endometrium and the conceptus and between the cell types within the endometrium. We believe that such models may be developed using the cells of the porcine endometrium harvested by enzymatic dispersion and with the aid of sieve separation. In this review, we consider the products of the pig endometrium and the expression of specific cell types when grown in primary cultures. We have not attempted to passage pig endometrial cells and do not know what effect that might have on their secretion of various products.

\section{Endometrial Cells in Primary Culture}

The endometrium is composed of two distinct epithelial populations (luminal and glandular) and a stroma that contains a variety of cell types. These cell types, the conceptus, and the potential interactions are illustrated (Fig. 1).

Procedures for harvesting and growing pig endometrial cells in vitro have been described (Zhang et al., 1991). These initial methods proved less than satisfactory for luminal epithelial cells. More recently, Y. Zhang (unpublished) in our laboratory has modified these procedures. To improve the yield and growth of luminal epithelial cells, we currently digest the cells at room temperature with dispase $(0.48 \%)$ for $20 \mathrm{~min}$ followed by digestion with dispase $(0.48 \%)$ /pancreatin $(1.25 \%)$ for $2 \mathrm{~h}$. The flask is shaken vigorously every $20-30 \mathrm{~min}$. This solution is then removed and the tissue rinsed two to three times. The initial solution and rinses contain the luminal epithelial cells. The cells are pelleted by centrifugation $(200 \mathrm{~g}$ for $10 \mathrm{~min}$ ). The remaining endometrial tissue is cut into small strips (approximately $1 \mathrm{~mm}$ in diameter) and processed for glandular and stromal cell isolation (Zhang et al., 1991). 
(a)

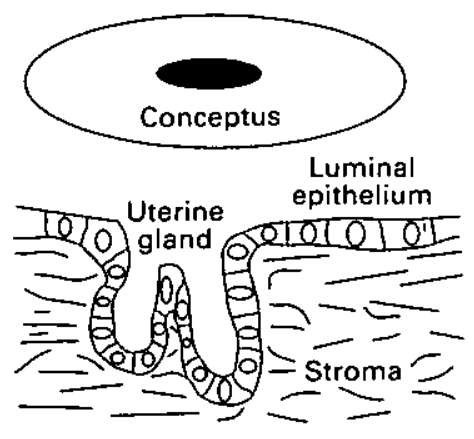

(b)

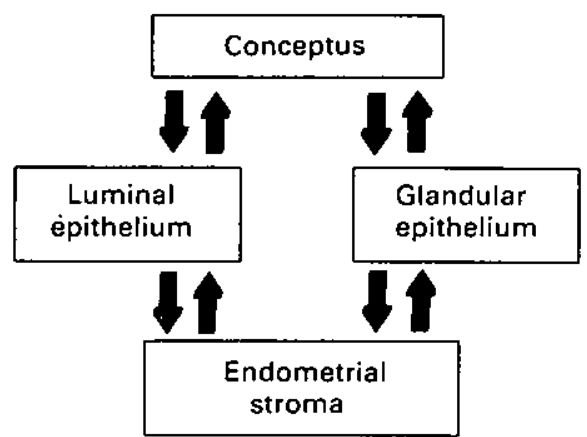

Fig. 1. (a) The tissues contributing to the uterine luminal environment and (b) the potential interactions between the tissues.

It is necessary to determine the secretory products of endometrial cells, the regulation of those secretions, and how these phenomena compare with the situation in vivo to characterize these cultures fully. Only limited information is available to describe the secretions of cultured endometrial cells. Here, we present a brief review of two classes of endometrial secretion, proteins and prostaglandins, and for each class, we present the available evidence for cell-type specific secretion.

\section{Proteins Secreted by the Pig Endometrium}

Information concerning protein secretions of the pig endometrium is summarized (Tables 1-3). A variety of proteins has been identified and information on the proposed functions of some of the proteins is available. Most of these proteins first appear during the peri-attachment period (days 11-14). Most of the proteins are probably regulated by progesterone, and secretion of some proteins is further modified by oestrogen (Geisert et al., 1982a, b). The uterine secretory proteins are useful markers for describing the phenotype of endometrial cells in culture. Conversely, culture of endometrial cells may provide information about their secretion and functions.

Uteroferrin is an iron-containing protein secreted by the progesterone-stimulated uterine glands of the pig endometrium and is secreted during the peri-implantation period. Secretion of uteroferrin increases markedly after day 30, is maximal at day 60, and then declines (Basha et al., 1979; Simmen et al., 1988 b). Uteroferrin mRNA expression follows a similar pattern, except that the message remains abundant in late gestation but translation decreases (Simmen et al., 1988b). Uteroferrin functions in iron transport to the fetus and has colony-forming unit activity (Bazer et al., 1991) and acid phosphatase activity. The latter property is not believed to function in the uterus but provides a convenient method for assaying the protein. Uteroferrin is secreted by glandular epithelial cells in vitro as indicated by western analysis of the culture medium and by the presence of acid phosphatase activity in the medium (Zhang et al., 1991). Culture media of the other two cell populations have not provided evidence for uteroferrin secretion. Uteroferrin secretion has been localized to the uterine glands in vivo by immunocytochemical methods (Fazleabas et al, 1985).

Another uterine protein that appears to function in nutrient transport is retinol-binding protein (RBP). RBP is thought to control the supply of vitamin A to the conceptus (Adams et al., 1981) and its expression appears to be induced by progesterone and modulated by oestrogen from the conceptus (Trout et al., 1992). Recently Groothuis and Davis (unpublished), using endometrial cell cultures and western analysis, found evidence for RBP in the culture media of glandular and luminal epithelial cells harvested from sows on day 13 of pregnancy.

The mRNAs for both insulin-like growth factor II (IGF-II) and its binding protein (IGFBP-2) have been demonstrated in both types of epithelial cell and in the endometrial stroma (Simmen et al., 1990) using enzymatic cell separation techniques. Expression of IGFBP-2, but not IGF-II, is induced by progesterone. 


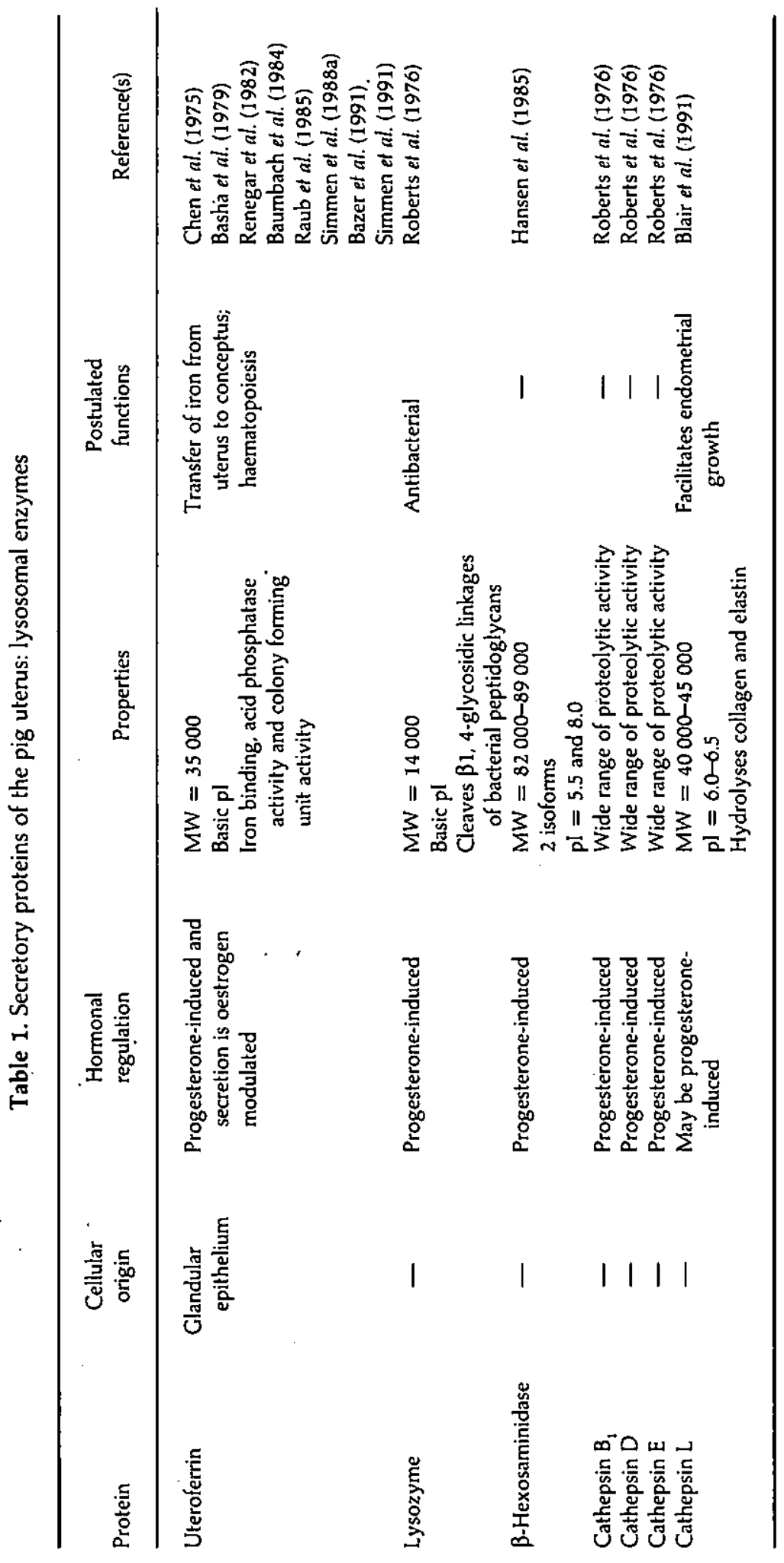




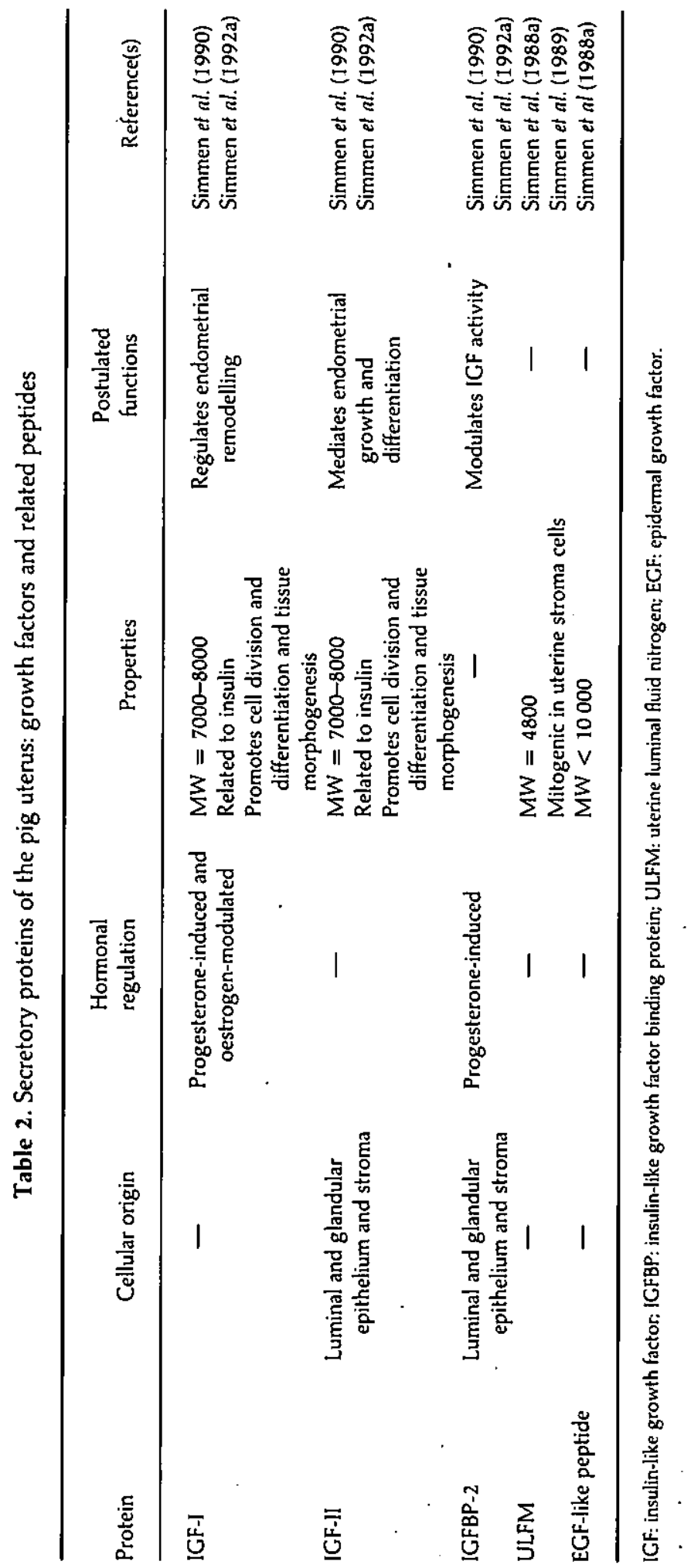




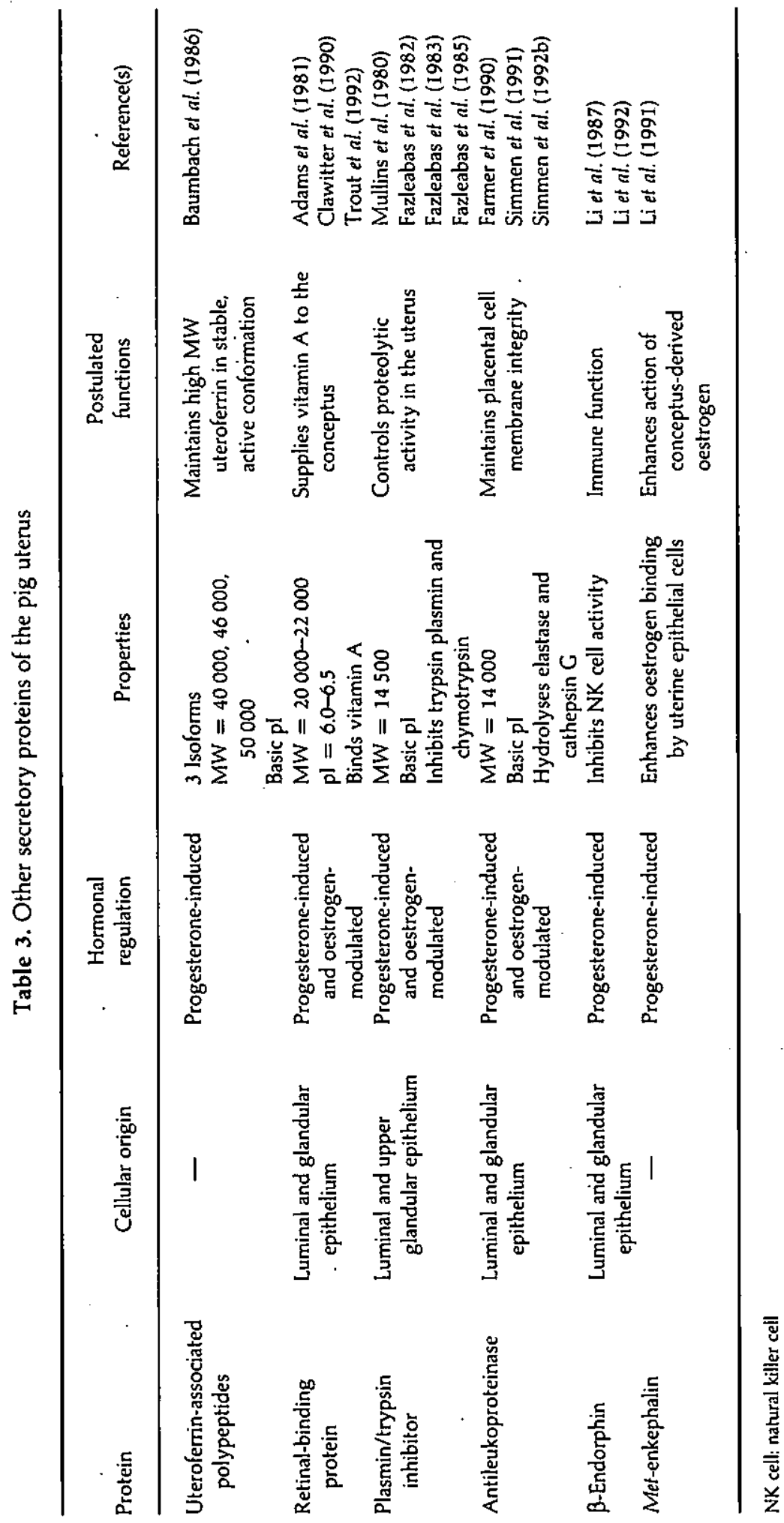


Further evidence for the involvement of growth factors in endometrial function comes from the report of Zhang et al. (1992), who found that both the stromal cells and glandular epithelial cells have epidermal growth factor receptors (EGF-R). These receptors are functional because EGF stimulates prostaglandin (PG) secretion by both types of cell. The ligand for this receptor may be transforming growth factor $\alpha$ (TGF- $\alpha$ ) synthesized by the conceptus (Vaughan et al., 1992), an EGF-like peptide in the uterine secretions (Simmen et al., 1988a), or another ligand from sources that are not yet identified.

A plasmin/trypsin inhibitor has been localized in the luminal and shallow glandular epithelium of the pig endometrium (Fazleabas et al., 1985). The inhibitor is induced by progesterone, and its secretion is further modulated by oestrogen (Fazleabas et al., 1982).

The opioid peptides represent another class of protein secreted by the pig endometrium. There is evidence for both $\beta$-endorphin ( $\mathrm{Li}$ et al., 1987, 1992) and met-enkephalin secretion ( $\mathrm{Li}$ et al., 1991). $\beta$ Endorphin is predominantly localized in the apical aspect of the luminal and glandular epithelium (Li $e t$ al., 1992). These opioids are induced by progesterone and are found during the peri-implantation period (Li et al., 1992).

The cellular origin of most of the uterine secretory proteins has not been determined. Separated cell types can be useful for determining cell-type specific secretion and has already been used to identify the localization of mRNAs for IGFs and IGFBP-2 (Simmen et al., 1991). Culture of these cell types will also be useful for determining the regulation of cell-type specific secretion. For example, progesterone induces uteroferrin secretion in vivo (Roberts and Bazer, 1988), and Zhang et al. (1990) observed that glandular epithelial cells secrete more uteroferrin, measured as acid phosphatase activity, when progesterone is present in their culture medium.

\section{Prostaglandin Secretion by the Pig Endometrium}

The endometrium is well known as a source of prostaglandins (PGs). The literature on endometrial production of PGs in pigs began over 17 years ago with the report of Patek and Watson (1976). Much attention has focused on the role of PGs in the uterine regulation of regression of the corpus luteum. Relatively little is known about the potential for PGs to regulate events associated with development of the pig conceptus and its attachment to the luminal epithelium. The roles for PGs in implantation in rodents have been the focus of attention (Kennedy, 1983; Malathy et al., 1986; Gupta et al., 1989). It is clear that in rats and mice the production of various prostanoids is tightly regulated at about the time of implantation and that both the blastocyst and the endometrium contribute to the prostanoid environment at the implantation site. Although the pig conceptus is less invasive in its attachment to the endometrium, many of the same signals may be operating at the attachment sites. Perhaps these events have received less attention in pigs because implantation is not easily monitored and spans several days. Other problems are the need to remove the uterus to monitor the progress of attachment and the need for careful work with the electron microscope to determine the earliest events. This is a physiological process that is ripe for the development of models in vitro.

All the cell types in the uterus and the conceptus secrete PGs. The complexity of this situation can be addressed by the separation and culture of individual endometrial cell types. In this section, we will outline our observations on the milieu of PGE and PGF in vivo and the production of these prostaglandins during the peri-implantation period by endometrial explants and the different types of endometrial cells in culture. The first attachment of the conceptus to the endometrium occurs on day 13 (Keys et al., 1986), beginning in the region of the embryonic disc and extending towards the extremities of the chorion (Keys and King, 1990). All stages of attachment, including interlocking microvilli, are present at the earliest attachment (Keys and King, 1990), and the process of attachment continues at least to day 26 (Dantzer, 1985). We have collected data over two periods: at initial attachment on day 13 (periattachment) and during progressive attachment from day 17 to day 19. Paria and Rosenkrans (1988) determined the PG environment in the uterine lumen during these two periods, the accumulation of PGs in the culture medium of endometrial explants and the content of PGs in the endometrial tissue (Fig. 2). In other studies, we determined the PG secretory characteristics of endometrial cells harvested on different days of pregnancy (Zhang and Davis, 1991 and unpublished) (Fig. 3). 

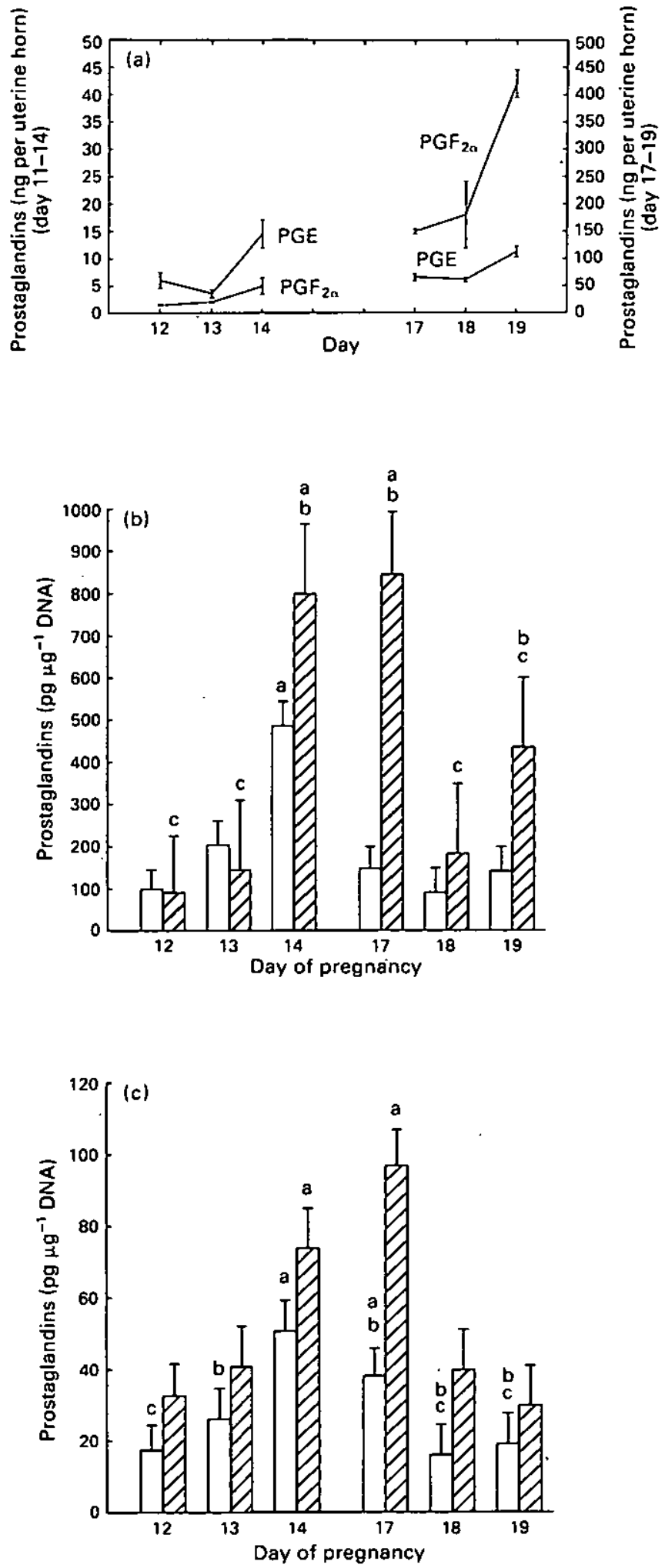
Prostaglandins in the uterine flushings present a dynamic picture, with an approximately tenfold increase in the amounts of PGs recovered from the uterine lumen between the peri-attachment period and the later period of progressive attachment. An additional difference is seen in the relative amounts of the two prostaglandins: PGE is relatively more abundant during the first period at initial attachment but, later, PGF predominates quantitatively. These data reflect contributions from both endometrium and conceptus. The endometrium itself shows an increased content and release of both PGs during an $8 \mathrm{~h}$ culture of explanted tissue. This result could reflect both endometrial production and a contribution of conceptus PGs that are taken up by the endometrium and released during culture. We therefore examined the PG secretion of individual types of cell after growth in vitro to determine the specific contribution of the endometrium (Fig. 3). These data provided some interesting insights. First, the glandular epithelium produces more PGF than PGE, whereas the stroma produces more PGE than PGF. This relative difference in secretion is also present when cells are incubated with $\left[{ }^{3} \mathrm{H}\right]$ arachidonic acid and the radioactive products determined (Blair, unpublished). Second, these relationships are altered by the conceptus. When the endometrial cells are harvested from pregnant pigs, the PGE:PGF secreted by stromal cells is increased over that observed when the cells are harvested from cyclic females (Fig. 4) (Zhang et al., 1991). We recently repeated this comparison and obtained similar results ( $\mathrm{P}$. Groothius, unpublished). Conceptus signals therefore result in an alteration in stromal cell PG synthesis that the cells 'remember' for a few days in culture. Longer studies have not been conducted.

The data from two studies addressing the question of effects of day of pregnancy are presented (Fig. 3). The initial studies of Zhang and Davis (1991) indicated that the day of pregnancy on which the cells are harvested affects their PG secretion. The PGE secretion by stromal cells harvested on day 13 increased markedly over the secretion by cells harvested on the 2 previous days. In another study with cells harvested on days 13 and 14 (Zhang and Davis, unpublished), it appeared that the heightened production of both PGs may extend to day 14. These observations probably reflect regulations in the pregnant uterus. Basha et al. (1979) observed that the secretory activity of pig endometrial explants depended on the physiological status of the donor. Furthermore, the similarity of the profiles of the endometrial explants and the glandular cells is consistent with the glandular cells being a major contributor to the luminal prostaglandin environment.

At present we can only speculate about the functions of these PG profiles, but their proximity to initial attachment of the conceptus to the endometrium is intriguing. PGE receptors have been detected in the pig endometrium (Kennedy et al., 1986). The vascular effects associated with initial attachment include increased blood flow (Ford et al., 1982a, b) and increased vascular permeability (Keys et al., 1986; Keys and King, 1988). PG involvement in these responses to the attaching conceptus is tenable, and PGs have been implicated in a similar phenomenon in the peri-implantation uterus of other species (Kennedy, 1983). Furthermore, treatment of gilts with indomethacin, a PG synthase inhibitor, interferes with pregnancy (Kraeling et al., 1985).

PGE and PGF are secreted by multiple cell types, and there are multiple regulators of their secretion. Cell types also vary in their response to some of the regulators (Zhang and Davis, 1992; Zhang et al., 1992) and endometrial cell types differ in their relative production of PGE and PGF (Fig. 2). Because PGE and PGF differ in many of their actions, PGE:PGF may integrate information from different sources to contribute to an appropriate environment in each micro-region of the uterine lumen. Such a potential system is illustrated (Fig. 5) and might be particularly effective for subtly shifting micro-environments to fine-tune responses within a complex milieu. Presently, this concept is hypothetical but could explain how multiple endometrial cell types and the conceptus can produce and respond to the same signals without confusion.

Fig. 2. (a) Prostaglandin content of the luminal flushings from one uterine hom on various days of pregnancy. Flushings were centrifuged $\left(2000 \mathrm{~g}\right.$ ) for $15 \mathrm{~min}$ at $5^{\circ} \mathrm{C}$ and supernatants assayed. (b) (D) PGE and (W) PGF in the culture medium of endometrial explants harvested on the indicated days of pregnancy and incubated for $8 \mathrm{~h}$ as described by Rosenkrans et al. (1990). Means within PG type without common superscripts are significantly different $(P<0.01)$. Data are expressed as $\mathrm{pg} \mu \mathrm{g}^{-1} \mathrm{DNA}$ in the explant. (c) Endometrial content of PGs Tissue was frozen in the presence of indomethacin $\left(10 \mu \mathrm{g} \mathrm{ml}^{-1}\right)$ and later thawed, homogenized, extracted with ethyl acetate and (D) PGE and ( $P$ PGF in the extract determined by radioimmunoassay. Means within PG type without common superscripts are significantly different $(P<0.01)$. 

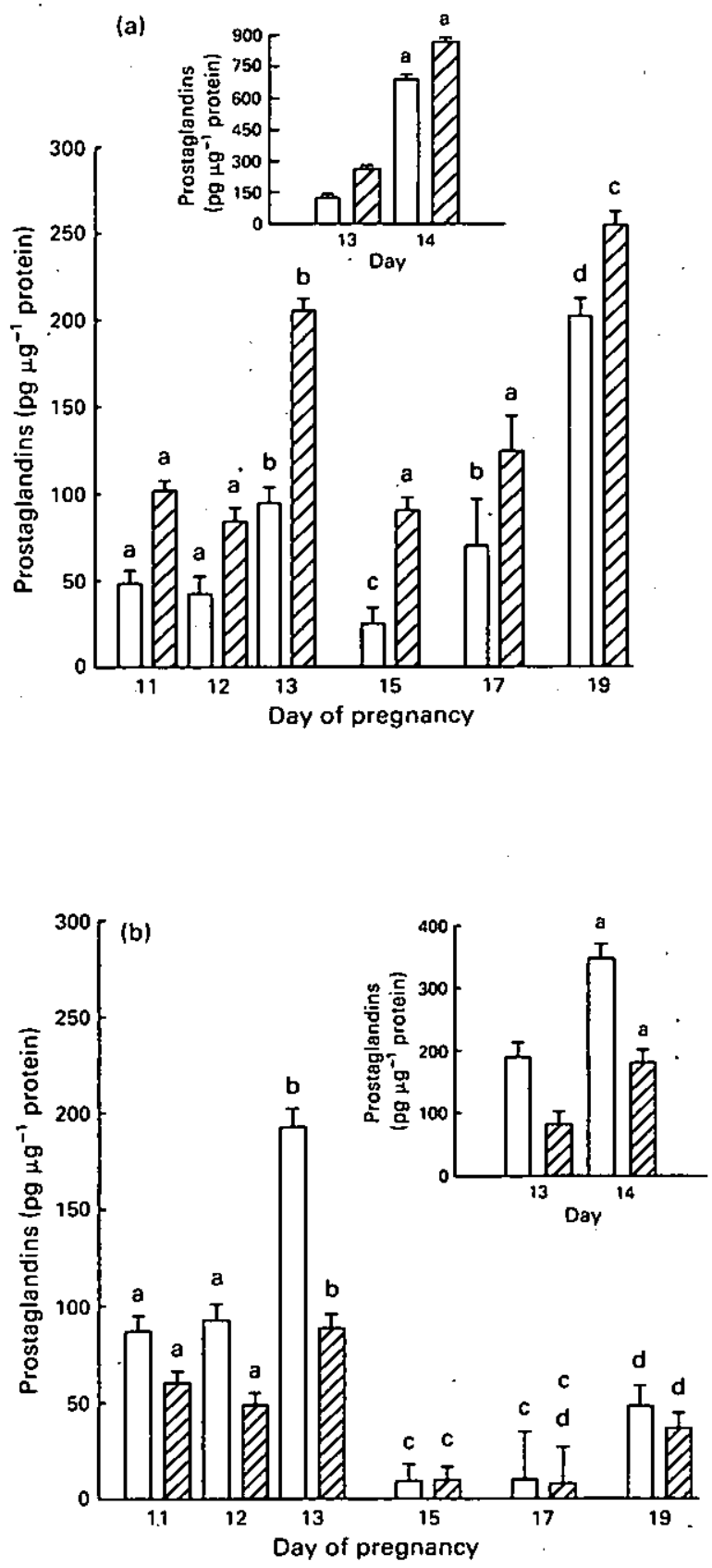

Fig. 3. Secretion of ( $\square$ ) PGE and (囚) PGF into the culture medium by cells harvested on various days of pregnancy. Data from Zhang and Davis (1991) are presented in the larger graphs, and the insets depict results of an unpublished study by Zhang and Davis. Data are expressed per $\mu \mathrm{g}$ cell protein and represent PGs secreted during $24 \mathrm{~h}$. (a) Cultures of glandular cells. (b) Cultures of stromal cells. Means within PG type without common superscripts are significantly different $(P<0.05)$. 


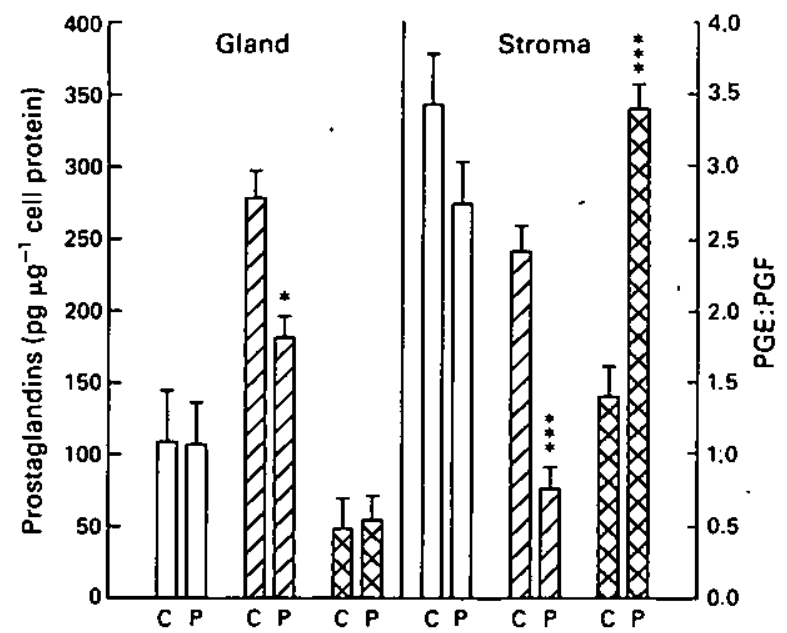

Fig. 4. Secretion of prostaglandins ( $\square$ ) PGE, ( $\triangle)$ PGF and $(\otimes)$ PGE:PGF by endometrial cells harvested from sows on day 13 of pregnancy $(\mathrm{P})$ or the oestrous cycle $(\mathrm{C})$. Data represent production of the PGs during $24 \mathrm{~h}$. Pregnancy effects indicated by ${ }^{*}(P<0.05)$ and ${ }^{* * *}(P<0.001)$. (Redrawn from Zhang $e t$ al., 1991a.)
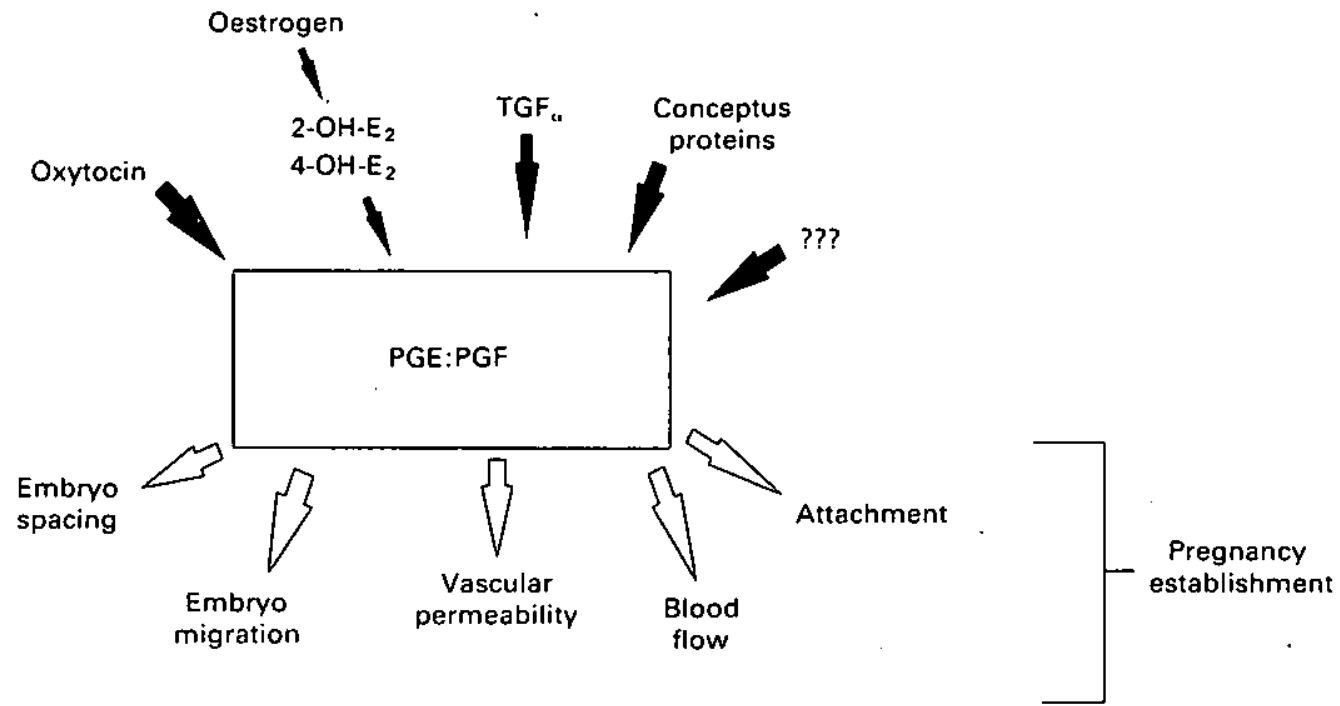

Fig. 5. A proposed model to explain the regulation and action of multiple sources of prostaglandins (PGE: PGF). The figure illustrates multiple regulators of PG secretion (solid arrows) and multiple sites of action

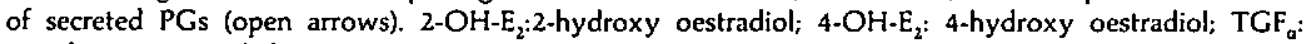
transforming growth factor $\alpha$.

\section{Conclusions}

Study of the pig endometrium has provided many insights into the physiology of early pregnancy. However, much remains to be learned about the functions and regulations of endometrial secretions. In addition, important aspects of the role of the endometrium in pregnancy are not addressed by present concepts. For example there is no explanation for the required synchrony between the embryo and uterus before day 10, and the implications of progesterone control of the uterine environment from day 4 to day 
10 are not understood. Almost all of the uterine secretory proteins appear after day 10. During later stages of pregnancy, how does the endometrium respond to the conceptus when space per conceptus is 'roomy' versus 'crowded'? Are there endometrial adaptations to the crowded situation that can be exploited to increase litter size? These examples illustrate that the endometrium and its secretions will remain fertile areas for research for some time.

Contribution No. 93-408-J from the Kansas Agricultural Experiment Station. Part of the research in this paper was supported by NIH grant HD 26762-02.

\section{References}

Adams KL, Bazer FW and Roberts RM (1981) Progesteroneinduced secretion of a retinol-binding protein in the pig uterus Joumal of Reproduction and Fertility 62 39-47

Basha SMM, Bazer FW and Roberts RM (1979) The secretion of a uterine specific, purple phosphatase by cultured explants of porcine endometrium: dependency upon the state of pregnancy of the donor animal Biology of Reproduction 20 $431-441$

Baumbach GA, Saunders PTK, Bazer FW and Roberts RM (1984) Uteroferrin has $N$-linked, high mannose oligosaccharides which contain mannose- 6 -phosphate Proceedings of the National Academy of Sciences USA 81 2985-2989

Baumbach GA, Ketcham CM. Richardson DE, Bazer FW and Roberts RM (1986) Isolation and characterization of a high molecular weight, stable pink form of uteroferrin from uterine secretions and allantoic fuid of pigs Joumal of Biological Chemistry 261 12869-12878

Bazer FW, Worthington-White D, Fliss MFV and Gross S (1991) Uteroferrin: a progesterone-induced hematopoietic growth factor of uterine origin Experimental Hematology 19 910-915

Blair RM, Rehberger T, Zavy MT and Yellin T (1991) Characterization and proteolytic activity of cathepsin L in endometrium and uterine fushings of cyclic and pregnant gilts Biology of Reproduction 46 (Supplement 1) 143

Chen TT, Bazer FW, Gebhardt BM and Roberts RM (1975) Uterine secretions in mammals: synthesis and placental transport of a purple acid phosphatase in pigs Biology of Reproduction 13 304-313

Clawitter J, Trout WE, Burke MG, Araghi S and Roberts RM (1990) A novel family of progesterone-induced, retinolbinding proteins from uterine secretions of the pig Joumal of Biological Chemistry 265 3248-3255

Dantzer V (1985) Electron microscopy of the initial stages of placentation in the pig Anatomy and Embryology 172 281-293

Davis DL. (1985) Culture and storage of pig embryos founal of Reproduction and Fertility Supplement 33 115-124

Farmer S], Fliss AE and Simmen RCM (1990) Complementary DNA cloning and regulation of expression of the messenger RNA encoding a pregnancy-associated porcine uterine protein related to human antileukoproteinase Molecular Endocrinology 4 1095-1104

Fazleabas AT, Bazer FW and Roberts RM (1982) Purification and properties of a progesterone-induced plasmin/trypsin inhibitor from uterine secretions of pigs and its immunocytochemical localization in the pregnant utenus joumal of Biological Chenistry $2576886-6897$

Fazleabas AT, Geisert RD, Bazer FW and Roberts RM (1983) Relationship between release of plasminogen activator and estrogen by blastocysts and secretion of plasmin inhibitor by uterine endometrium in the pregnant pig Biology of Reproduction 29 225-238
Fazleabas AT, Bazer FW, Hansen PJ, Geisert RD and Roberts RM (1985) Differential patterns of secretory protein localization within the pig uterine endometrium Endocrinology 110 240-245

Ford SP, Christenson SK and Ford JJ (1982a) Uterine blood flow and uterine arterial, venous and luminal concentrations of estrogens on days 11,13 and 15 after oestrus in pregnant and non-pregnant sows Joumal of Reproduction and Fertility $64185-190$

Ford SP, Reynolds LP and Magness RR (1982b) Blood flow to the uterine and ovarian vascular beds of gilts during the estrus cycle or early pregnancy Biology of Reproduction 27 878-885

Galvin JM, Cantley TC and Day BN (1990) Effect of ovariectomy on days 4 or 6 of gestation on embryonic development and survival in gilts Joumal of Animal Science 68 (Supplement I) 129

Galvin JM, Cantley TC and Day BN (1992) Effect of ovarjectomy and progesterone replacement therapy on elongation of pig conceptuses in vivo Journal of Animal Science 70 (Supplement 1) 272

Geisert RD, Renegar RH, Thatcher WW, Roberts RM and Bazer FW (1982a) Establishment of pregnancy in the pig: 1. Interrelationships between preimplantation development of the pig blastocyst and uterine endometrial secretions Biology of Reproduction 27 925-939

Geisert RD, Renegar RH, Thatcher WW, Roberts RM and Bazer FW (1982b) Establishment of pregnancy in the pig: Ill. Endometrial secretory response to estradiol valerate administered on day 11 of the estrous cycle Biology of Reproduction 27 957-965

Gupta A, Huet YM and Dey SK (1989) Evidence for prostaglandins and leukotrienes as mediators of phase I of estrogen action in implantation in the mouse Endocrinology 124 546-548

Hansen PJ, Bazer FW and Roberts RM (1985) Appearance of $\beta$ hexosaminidase and other lysosomal-like enzymes in the uterine lumen of gilts, ewes and mares in response to progesterone and aestrogens Joumal of Reproduction and Fertility $73411-424$

Kennedy TG (1983) Embryonic signals and the initiation of blastocyst implantation Australian Joumal of Biological Science 36 531-543

Kennedy TC, Key JK and King GJ (1986) Endometrial prostaglandin $\mathrm{E}_{3}$-binding sites in the pig: characterization and changes during the estrous cycle and early pregnancy Biology of Reproduction 35 624-632

Keys JL and King GJ (1988) Morphological evidence for increased uterine vascular permeability at the time of embryonic attachment is the pig Biology of Reproduction 39 473-487

Keys IL and King GJ (1990) Microscopic examination of porcine conceptus-maternal interface between days 10 and 
19 of pregnancy The American Joumal of Anatomy 188 221-238

Keys JL, King GJ and Kennedy TG (1986) Increased uterine vascular permeability at the time of embryonic attachment in the pig Biology of Reproduction 34 405-411

Kraeling RR, Rampacek GB and Fiorello NA (1985) Inhibition of pregnancy with indomethacin in mature gilts and prepubertal gilts induced to ovulate Biology of Reproduction $\mathbf{3 2}$ 105-110

Li WI, Chen CL. Hansen PJ and Bazer FW (1987) $\beta$-Endorphin in uterine secretions of pseudopregnant and ovariectomized, ovarian steroid-treated gilts Endocrinology $1211111-1115$

Li WI, Sung L.C and Bazer FW (1991) Immunoreactive methionine-enkephalin secretion by porcine uterus Endocrinology 128 21-26

Li WI, Wu H and Chen C-L. (1992) Endometrial immunoreactive $\beta$-Endorphin increases during mid-estrous cycle and early pregnancy in gilts Biology of Reproduction 46 740-746

McCrae AC (1988) The blood-uterine lumen barrier and exchange between extracellular fluids jounal of Reproduction and Fertility 82 857-873

Malathy PV, Cheng HC and Dey SK (1986) Production of leukotrienes and prostaglandins in the rat uterus during periimplantation period Prostaglandins 32 605-614

Multins DE, Bazer FW and Roberts RM (1980) Secretion of a progesterone-induced inhibitor of plasminogen activator by the porcine uterus Cell 20 865-872

Paria BC and Rosenkrans CF, Jr (1988) Prostaglandin production by endometrial and conceptus tissues of the pig Biology of Reproduction 38 (Supplement 1) 79

Patek CE and Watson J (1976) Prostaglandin F and progesterone secretion by porcine endometrium and the corpus luteum in vitro Prostaglandins 12 97-111

Polge $C$ (1982) Embryo transplantation and preservation. In Control of Pig Reproduction pp 277-291 Ed. DJA Cole and GR Foxcroft. Butterworth Scientific, London

Pope WF. Xie S, Broermann DM and Nephew KP (1990) Causes and consequences of early embryonic diversity in pigs Jounul of Reproduction and Fertility Supplement 40 3-17

Raub TJ, Bazer FW and Roberts RM (1985) Localization of the iron transport glycoprotein, uteroferrin, in the porcine endometrium and placenta by using immunocolloidal gold Anatomy and Embryology 171 253-258

Renegar RH, Bazer FW and Roberts RM (1982) Placental transport and distribution of uteroferrin in the fetal pig Biology of Reproduction 27 1247-1260

Roberts RM and Bazer FW (1988) The function of uterine secretions Jounul of Reproduction and Fertility 82 875-892

Roberts RM, Bazer FW, Baldwin N and Pollard WE (1976) Progesterone induction of lysozyme and peptidase activities in the porcine uterus Archives of Biochemistry and Biophysics 177 499-507

Rosenkrans CF. Jr, Paria BC, Davis DL, and Milliken J (1990) In vitro synthesis of prostaglandin $E$ and $F 2 \alpha$ by pig endometrium in the presence of estradiol, catechol estrogen and ascorbic acid journal of Animal Science 68 435-443

Simmen RCM and Simmen FA (1990) Regulation of uterine and conceptus secretory activity in the pig Jounal of Reproduction and Fertility Supplement 40 279-292

Simmen RCM, Ko Y, Liu XH, Wilde MH, Pope WF and Simmen FA (1988a) A uterine cell mitogen distinct from epidermal growth factor in porcine uterine luminal fuids: characterization and partial purification Biology of Reproduction 38 $551-561$
Simmen RCM, Baumbach GA and Roberts RM (1988b) Molecular cloning and temporal expression during pregnancy of the messenger ribonucleic acid encoding uteroferrin, a progesterone-induced uterine secretory protein Molecular Endocrinology 2 253-262

Simmen RCM, Simmen FA, Ko Y and Bazer FW (1989) Differential growth factor content of uterine luminal fluids from Large White and prolific Meishan pigs during the estrous cycle and early pregnancy Joumal of Animal Science 67 1538-1545

Simmen RCM, Simmen FA, Hofig A, Farmer SJ and Bazer FW (1990) Hormonal regulation of insulin-like growth factor gene expression in pig uterus Endocrinology 127 2166-2174

Simmen RCM, Simmen FA and Bazer FW (1991) Regulation of synthesis of uterine secretory proteins: evidence for differential induction of porcine uteroferrin and antileukoprotein. ase gene expression Biology of Reproduction 44 191-200

Simmen FA. Simmen RCM, Geisert RD, Martinat-Botte F, Bazer FW and Terqui $M$ (1992a) Differential expression, during the estrous cycle and pre- and postimplantation conceptus development, of messenger ribonucleic acids encoding components of the pig uterine insulin-like growth factor system Endocrinology 130 1547-1556

Simmen RCM, Michel FJ, Fliss AE, Smith LC and Fliss MFV (1992b) Ontogeny, immunocytochemical localization, and biochemical properties of the pregnancy-associated uterine elastase/cathepsin-G protease inhibitor, Antileukoproteinase (ALP): monospecific antibodies to a synthetic peptide recognize native ALP Endocrinology 130 1957-1965

Trout WE, Hall JA, Stallings-Mann ML, Galvin JM, Anthony RV and Roberts RM (1992) Steroid regulation of the synthesis and secretion of retinol-binding protein by the uterus of the pig Endocrinology 130 2557-2564

Vaughan TJ, James PS, Pascall JC and Brown KD (1992) Expression of the genes for TGFa, EGF and the EGF receptor during early pig development Development 116 663-669

Webel SK, Peters JB and Anderson LL (1970) Synchronous and asynchronous transfer of embryos in the pig joumal of Animal Science 30 565-568

Zhang $Z$ and Davis DL (1991) Prostaglandin $E$ and $F_{2} \alpha$ secretion by glandular and stromal cells of the pig endometrium in vitro: effects of estradiol-17\%. progesterone, and day of pregnancy Prosiaglandins 42 151-162

Zhang Z and Davis DL (1992) Cell-type specific responses in prostaglandin secretion by glandular and stromal cells from pig endometrium treated with catecholestrogens, methoxyestrogens and progesterone Prostaglandiss 44 53-64

Zhang Z, Davis DL and Krause M (1990) Secretion of uteroferrin by the glandular epithelium of pig endometrium in vitro: persistence of secretion and effects of progesterone. estradiol and prolactin Biology of Reproduction 42 (Supplement 1) 98

Zhang Z, Paria BC and Davis DL. (1991) Pig endometrial cells in primary culture: morphology. secretion of prostaglandins and proteins, and effects of pregnancy Joumal of Animal Science 69 3005-3015

Zhang Z, Krause $M$ and Davis DL (1992) Epidermal growth factor receptors in porcine endometrium: binding characteristics and the regulation of prostaglandin $E$ and $F_{2} \alpha$ production Biology of Reproduction $46932-936$ 